\title{
TALKING ABOUT HARASSMENT
}

\section{Vicki Schultz*}

I am delighted to be here with such a distinguished and wonderful group of people to celebrate the thirty-fifth anniversary of the Harvard Civil Rights-Civil Liberties Law Review. It is a great opportunity for all of us to talk to each other about what has been happening in the field of sex harassment law.

I do not think it is fair to say, as some people have suggested, that the fundamental rethinking of harassment law that is going on right now is a backlash against women, or feminists. ${ }^{1}$ There are many feminists and gay rights activists and queer theorists of good will who are going back to square one to figure out whether harassment law is doing the work it should be doing. ${ }^{2}$ I am such

* Professor, Yale Law School; Evelyn Green Davis Fellow, Bunting Fellowship Program, Radcliffe Institute for Advanced Study, 2000-2001. I would like to thank the Harvard Civil Rights-Civil Liberties Law Review for inviting me to appear on this panel, which was chaired brilliantly by Professor Janet Halley. I would also like to thank my fabulous research assistant Jamie Kohen for her able assistance with sources.

${ }^{1}$ Catharine A. MacKinnon, Harassment Law Under Siege, N.Y.TIMES, Mar. 5, 1998, at A29 ("The insidious argument that sexual harassment law turns 'all sex into harassment' epitomizes the current backlash."). Cf. Tamar Lewin, Debate Centers on Definition of Harassment, N.Y.TIMES, Mar. 22, 1998, at A1 (describing the so-called "Seinfeld" case, see infra note 45, as an apparent case of backlash against sexual harassment law); Kate Zernike, A New Sexual Harassment Dynamic, Boston GloBe, May 18, 1998, at A1 (describing the current backlash of men filing harassment claims).

${ }^{2}$ See Drucilla Cornell, The Imaginary Domain 190-96 (1995) (criticizing earlier theories of harassment for protecting "good girls" from sexual advances, rather than placing all women in charge of their own sexual desire); Kathryn Abrams, The New Jurisprudence of Sexual Harassment, 83 CORNELL L. REV. 1169, 1205-12 (1998) (criticizing earlier theories of harassment for negating women's sexual agency); Katherine M. Franke, What's Wrong With Sexual Harassment? 49 STAN. L. REV. 691, 729-62 (1997) (criticizing earlier theories of harassment for neglecting same-sex sexual harassment). 
a person. ${ }^{3}$ I have come to believe that we need to fundamentally change the way we think about harassment. In my view, we need to move away from the model that has prevailed over the last twenty years. In an earlier work I have referred to this model as the sexual desire-dominance model, ${ }^{4}$ but today I am going to call it the sexual model for short.

Under the sexual model, the quintessential case of harassment involves a powerful, typically older male boss who makes unwanted sexual advances toward a less powerful female subordinate. The Anita Hill-Clarence Thomas controversy, the Tailhook incident, the Stroh's Brewery lawsuit, the Paula Jones case - in fact, almost all of the harassment cases that have been publicized widely in the news media - conform to this sexual model. ${ }^{5}$ I have come to believe that this is a fundamentally misguided way to think about sex harassment. It has taken me a great deal of time and effort to come to this position, and I have only a few minutes today to talk to you about why.

One problem with the sexual model is that it is top-down; indeed, the entire conception of dominance and subordination that is used in some of the literature is top-down. ${ }^{6}$ Top-down models

${ }^{3}$ In both the scholarly and popular literature, I have developed a fundamental critique of one version of sex harassment law. See generally Vicki Schultz, Reconceptualizing Sexual Harassment, 107 YALE L. J. 1683 (1998) [hereinafter Schultz, Reconceptualizing Sexual Harassment]; Vicki Schultz, Sex Is the Least of It: Let's Focus Harassment Law on Work, Not Sex, THE NATION, 19 Vol. 266, May 25, 1998, at 11; see also Ellen Yarosnefsky, More Than Sex: Why the Courts Are Missing the Point; An Interview with Vicki Schultz, MS. MAGAZINE, May 1998, at 56-61.

${ }^{4}$ Schultz, Reconceptualizing Sexual Harassment, supra note 3, at 1692-711.

${ }^{5}$ For a description of how Hill-Thomas, Tailhook, and the Stroh's cases conformed to the sexual paradigm, see Schultz, Reconceptualizing Sexual Harassment, supra note 3, at nn.19-45 and accompanying text; see also Jones v. Clinton, 72 F.3d 1354 (8th Cir. 1996), aff'd, Clinton v. Jones, 520 U.S. 681 (1997).

${ }^{6}$ See, e.g., CATHARINE MACKINNON, TOWARD A FEMINIST ThEORY OF THE STATE 137 (1989) (arguing that "sexuality is the dynamic of control by which male dominance - in forms that range from intimate to institutional, from a look to a rape - eroticizes and thus defines man and woman, gender identity and sexual pleasure" and that sexuality is "that which maintains and defines male supremacy as a political system"). Cf. Ruth Colker, Anti-Subordination Above 
assume that power follows from formal roles and that it flows from those who occupy higher positions down onto those who occupy lower positions. Yet power is not always contained in formal structures, and it can circulate in many unexpected directions. In the workplace, many women (and men) experience horizontal harassment that involves exclusion by peers, not simply vertical harassment that involves coercion from bosses. Indeed, the day-today interactions through which co-workers create relationships that mark some people as insiders and other people as outsiders are a crucial part of the dynamic that sustains sex segregation and hierarchy in the workplace. Harassment is not always about who is on top and who is on bottom; it is also about who is "in" and who is "out."

I want to move our legal and cultural understanding of sex harassment toward a model that places exclusion from work, rather than abuse of sexuality, at the forefront. The sexual model treats harassment as a way for men to use work to appropriate sex from women. But we can also see harassment as a way for men (or women) to use sex to appropriate work for themselves. Some men resort to sexual assault, along with other behaviors that intimidate and exclude women, as a way to claim the best jobs as masculine terrain.

Work is one of the most important distributional goods that exists in our society; it provides the foundation for citizenship, economic security, community, and self-esteem. ${ }^{7}$ Indeed, work is central to most people's sense of themselves, ${ }^{8}$ including their sense

All: Sex, Race, and Equal Protection, 61 N.Y.U. L. REV. 1003 (1986) (proposing a framework for evaluating sex discrimination based on eradicating the subordination of women to men).

${ }^{7} \mathrm{I}$ discuss these issues in more detail in a recent essay. See Vicki Schultz, Life's Work, 100 CoLUM. L. REV. 1881 (2000). For references to the literature documenting the significance of work, see id. at 1886-92, 1908-10, 1930-31; see also William E. Forbath, Caste, Class and Equal Citizenship, 98 MICH. L. REV. 1, 19-21, 90 (1999) (emphasizing the importance of work to equal citizenship); Kenneth L. Karst, The Coming Crisis of Work in Constitutional Perspective, 82 CORNELL L. REV. 523, 530-33 (1997) (describing the importance of work to personal identity, community, and equal citizenship).

${ }^{8}$ For a more thorough elaboration of this point, see Schultz, Life's Work, supra note 7 , at $1890-91$. 
of themselves as men or women. So, it should not surprise us that some men will try to monopolize good jobs to safeguard their economic superiority and to secure their manly identities. Male workers can define their jobs as the domain of those who are suitably "masculine," for example, by driving away the women and even men who do not fit the projected masculine image, or by marking those who remain as different and inferior.

Once we make this shift away from the sexual model toward a work-centered model, we can see many issues through a different lens. Take, for example, the issue of sex segregation and harassment among school children. I once wrote an article in which I argued that occupational segregation by sex - or, the sex-type of the work people do as adults - cannot be attributed to sexism in early childhood socialization. ${ }^{9}$ The standard explanation for occupational segregation is that people are raised to prefer jobs that are coded as "feminine" or "masculine" - girls want to be nurses, boys want to be doctors - and they just follow in that trajectory when they grow up. I hope I persuaded some readers that this explanation fails: most people end up doing jobs that have very little to do with what they thought they would do when they were children, and the sex-type of the jobs to which they aspire as children does not predict the sex-type of the jobs they hold as adults. I still insist that I was right about that point.

But I do think I failed to appreciate how early in life the process of shaping gender identity by claiming certain activities as "masculine" (or "feminine") begins. I now have a four-year-old, and I have spent a lot of time in preschools and on playgrounds. I have seen first-hand how some groups of children try to claim certain play activities and playspaces as gendered, in the same way that some adults try to claim lines of work and workplaces as gendered. For example, at my daughter's preschool, when the teachers created a fantasy play structure that was a construction site, a group of the older boys claimed the site as a "boys"' space

${ }^{9}$ Vicki Schultz, Telling Stories About Women and Work: Judicial Interpretations of Sex Segregation in the Workplace in Title VII Cases Raising the Lack of Interest Argument, 103 HARV. L. REV. 1749, 1798-839 (1990) (arguing that early childhood socialization toward femininity and masculinity cannot explain the sex segregation of employment among adults). 
and coded construction as a "boys"' activity. Whenever the girls entered the site, these boys warned them away or ostracized them by hitting them, pressing their toy power tools against them, calling them "stupid," and refusing to play with them. Before long, even the girls who loved to play with construction toys at home internalized the message that, at school, construction was not for them. Although I have been amazed (and dismayed) to observe this process occur among young children, in hindsight I suppose it was predictable. Play serves the same functions for children that work serves for most adults. Through play, children explore their world, bond with others, obtain social recognition, express their creative energies, and develop their sense of themselves. So, just as work is one of the main activities through which people create their senses of themselves as (certain kinds of) "men" and "women," so, too, play is a central medium through which children begin to define themselves as (certain kinds of) "boys" (in this case, "bad boys") and "girls." Through this process, the psychological and institutional habits of exclusion begin. Once we see children's interactions from this perspective, it seems clear that we should be more concerned with these non-sexual, exclusionary patterns of behavior than with some of the comparatively benign, sexually themed incidents that have captured the attention of the schools and the national news media. ${ }^{10}$

We should focus our energy on the same sorts of patterns of gender-based exclusion among adults in our nation's workplaces. This is one of my major critiques of the sexual model: it has led courts and commentators to focus obsessively on sexual conduct, while deflecting our attention away from arguably more common, non-sexual forms of gender-based hostility and abuse that women (and many men) endure every day in workplaces all over the country. For my Yale Law Journal piece, I read hundreds and hundreds of harassment cases - almost every lower federal court sex harassment hostile environment case that was decided between

${ }^{10}$ See, e.g., Cynthia Gorney, Teaching Johnny the Appropriate Way to Flirt, N.Y. TIMES MAG., June 13, 1999, at 43 (describing an incident in which a schoolboy shapes a milk bag into a replica of a penis). Gorney also describes an incident in which a North Carolina school suspended a six-year-old boy for kissing a girl classmate on the cheek. Id. at 45 . 
the Supreme Court's 1986 decision in Meritor ${ }^{11}$ and its 1993 decision in Harris, ${ }^{12}$ as well as a large random sample of cases decided thereafter. ${ }^{13}$ Over and over again, I kept seeing the same pattern: when women entered fields that had been defined traditionally as "men's work," some of the men became very threatened by the women's presence. ${ }^{14}$ These men did all sorts of things to drive the women away or to mark them as less competent. The cases involve everything from genuine assaults - such as shoving file cabinets onto the women, pulling knives on them, or hitting, kicking and groping them ${ }^{15}$ - to everyday micro-aggressions such as excluding the women from social interactions and training, ${ }^{16}$ or picking on them constantly. ${ }^{17}$ Work sabotage is incredi-

${ }^{11}$ Meritor Savings Bank v. Vinson, 477 U.S. 57 (1986) (recognizing for the first time that a sex-based hostile work environment constitutes a form of sex discrimination under Title VII).

${ }^{12}$ Harris v. Forklift Sys., Inc., 510 U.S. 17 (1993).

${ }_{13}$ See Schultz, Reconceptualizing Sexual Harassment, supra note 3, at 1710 n.127 (describing methodology).

${ }^{14}$ This pattern is well documented in my earlier article. See Schultz, Reconceptualizing Sexual Harassment, supra note 3, at 1721-32, 1758-62 (describing harassment cases that conform to this pattern and reviewing the sociological and ethnographic literature that documents and explains this phenomenon). Many cases decided after the article was published still conform to this pattern. See, e.g., Conner v. Schrader-Bridgeport Intern, Inc., 227 F.3d 179 (4th Cir. 1999) (female automotive factory worker); Smith v. Sheahan, 189 F.3d 529 (7th Cir. 1999) (female guard at jail); Williams v. General Motors Corp., 187 F.3d 553 (6th Cir. 1999) (female factory worker); Richmond-Hopes v. City of Cleveland, 168 F.3d 490 (6th Cir. 1998) (female electric meter service installer); Durham Life Insurance Co. v. Evans, 166 F.3d 139 (3d Cir. 1999) (female insurance salesperson).

${ }^{15}$ See, e.g., Weinsheimer v. Rockwell Int'l Corp., 754 F. Supp. 1559 (M.D. Fla. 1990), aff'd, 949 F.2d 1162 (11th Cir. 1991) (male technician held a knife to plaintiff's throat, shoved her into a file cabinet, threatened to bang her head into the ground, and grabbed her pelvic area and breasts); Kirkland v. Brinias, 741 F. Supp. 692 (E.D. Tenn. 1989), aff'd, 944 F.2d 905 (6th Cir. 1991) (fiftyyear-old male busboy hit, kicked, and sexually groped the waitresses); see also Kirstin Dowley Grimsley, A Hostile Workplace: Into an Abyss of Sex Harassment At Eveleth Mine, WASH. POST, Oct. 27, 1996, at A01 (male miner slashed a gash in female miner's pant leg, drawing blood; another pressed his body against a female miner and then put his hands around her throat).

${ }^{16}$ See, e.g., Ezold v. Wolf, Block, Schorr \& Solis-Cohen, 983 F.2d 509, 
bly common. ${ }^{18}$ In some cases, men actually altered work machinery in ways that threatened women's safety; one woman had a hole drilled in her arm. ${ }^{19}$ In less dramatic cases, men stole women's case files, ${ }^{20}$ overburdened them with work, and engaged in more mundane activities to create the impression that the women were not doing their jobs well and did not belong there. ${ }^{21}$ In some

540-41 (3d Cir. 1993) (involving a law firm associate who claimed that she was denied the opportunity to work on large complex cases and was subsequently denied partnership on the ground that she lacked the capacity to handle such matters); Heim v. Utah, 8 F.3d 1541, 1543 (10th Cir. 1993) (involving a construction technician who claimed that she was denied the opportunity to obtain construction experience in the field); Scott v. Sears, Roebuck \& Co., 798 F.2d 210, 212 (7th Cir. 1986) (involving an auto mechanic trainee who claimed that she was denied the ability to learn to do brake repair and was subsequently fired on the ground that she was not productive at such work).

${ }^{17}$ See, e.g., Cross v. Alabama Dep't of Mental Health \& Mental Retardation, 49 F.3d 1490, 1497 (11th Cir. 1995) (psychiatric facility employees referred to as "rather dumb," "stupid," or "just a woman"); Davis v. Boeing Helicopter Co., No. 88-0281, 1990 U.S. Dist. LEXIS 11990, at *4 (E.D. Pa. Sept. 12, 1990) (involving a female aircraft assembler who was promoted to electrician and who claimed that her supervisor "harassed her and made it impossible for her to complete her work by checking her progress every few minutes"); Turley v. Union Carbide Corp., 618 F. Supp. 1438 (S.D. W. Va. 1985) (foreman harassed female employee by "picking on [her] all the time" and treating her differently from the male employees).

${ }^{18}$ See Schultz, Reconceptualizing Sexual Harassment, supra note 3, at 171328, 1734-38, 1748-55.

19 See MARY MARTIN, HaRD-HATTED WOMEN: STORIES OF STRUGGLE AND SUCCESS IN THE TRADES 33-34 (1988) ("[The men] didn't want the women to replace them, so they pulled stunts. Someone cut the chain holding up a big motor mount I was welding. It fell down on me and burned my arm to the bone."); id. at 257 ("I had to start checking all the parts on my machine because Dick would loosen stuff on it, which could kill you.").

${ }^{20}$ Andrews v. City of Philadelphia, 895 F.2d 1469, 1473 (3d Cir. 1990) (black female police officer contended her coworkers stole or hid her case files in an attempt to harass her).

${ }^{21}$ See, e.g., Lipsett v. Univ. of Puerto Rico, 864 F.2d 881, 910 (1st Cir. 1988) (reporting an allegation that a coworker "had falsified a medical record in an attempt to create the impression that the plaintiff and [another employee] had mishandled a case"); Berkman v. City of New York, 580 F. Supp. 226, 233 (E.D.N.Y. 1983), aff'd, 755 F.2d 913 (2d Cir. 1985) (involving female firefighters who were inadequately trained by officers who instead set out 
settings, of course, men resorted to sexual assaults and crude sexual advances to threaten the women and undermine their perceived professionalism. But in most cases, such sexual misconduct was part of a larger pattern to exclude the women or to communicate the message that they are different or inferior.

The sexual model has created another related problem. It encourages people to think of harassment as a form of behavioral misconduct in which individual bad actors engage, rather than as a set of social relations that are embedded in a larger context of structural inequality in the workplace. As a result, sex harassment policies have become stand-alone policies that are completely divorced from the larger policies designed to achieve gender integration. I did some research a couple of years ago and interviewed a number of managers and management consultants. Almost all of them defined sex harassment primarily, if not exclusively, in terms of sexual misconduct. They had adopted isolated policies and procedures for dealing with sex harassment, rather than dealing with it as an aspect of a broader anti-discrimination program. Unfortunately, they did not see eradicating harassment as part of a larger, more affirmative project of creating a company culture that is gender-integrated and welcoming to both sexes. These findings were surprising to me, because harassment is really just a type of

deliberately to undermine their physical capacity to do the job, and then terminated them at the end of their probation period); Beeman v. Safeway Stores, Inc., 724 F. Supp. 674, 675 (W.D. Mo. 1989) (reporting an allegation by a female grocery store manager that her boss harassed her by "making daily checks upon her work, ... belittling her performance, ... reprimanding her in meetings that lasted up to three hours, ... making long lists of things for her to do, ... [and] asking her to accomplish work tasks that were impossible to accomplish within the allotted time"); Downum v. City of Wichita, 675 F. Supp. $1566,1569-70$ (D. Kan. 1986) (involving a female firefighter who claimed she was rushed through training to be a dispatcher and made to do the job before she was ready); Hosemann v. Technical Materials, Inc., 554 F. Supp. 659 (D.R.I. 1982) (plaintiff's coworkers sabotaged her work and "always ... tried to make her do her work poorly"); Accardi v. Superior Court, 21 Cal. Rptr. 2d 292, 297 (Ct. App. 1993) (reporting a female police officer's allegation that her department undercut her performance by "deliberately overburdening her with double work assignments; denying assistance when she requested it; [and] deliberately circumventing established procedures when she was assigned to duty as a court officer in order to make her work more difficult"). 
discrimination. The whole concept of hostile work environment harassment emerged when judges realized that after many companies had ceased discriminating overtly, more covert barriers to integration had emerged. Rather than managers refusing to hire racial minorities or women, they could simply look the other way while incumbent workers drove the newcomers away. ${ }^{22}$ Once we understand that harassment is just a subtle type of discrimination designed to maintain traditional patterns of segregation, it seems clear that harassment policies should be integrated into more comprehensive organizational policies to achieve desegregation. Such policies must take into account the specific history and culture of the firm, the professional field in question, and the particular job setting.

Rather than facilitating such a fine-tuned sociological approach, the sexual model lends itself to a free-floating, trans-contextual analysis. Defining sex harassment as a form of sexual violation the "unwelcome sexual advance" - that transcends the particular organizational context makes it possible to essentialize the concept of harassment. Such an approach can translate readily into the proposition that men's sexual advances inherently violate women's dignity or equality. There is reason to be concerned that this is happening around the globe, as some nations have imported the sexual model of harassment that is now being questioned by feminists in the United States, and incorporated it into their own legal and cultural traditions. ${ }^{23}$ Following close on the heels of legal developments in the United States, for example, the European Union took steps to condemn and outlaw workplace sex harassment as a violation of women's dignity, while defining harassment in sexual terms strikingly similar to those promulgated by the United States EEOC. ${ }^{24}$ Austria passed a law that adopts both the sexual

${ }^{22}$ This pattern of management acquiescence in co-worker harassment is described in Martin, supra note 19; Wendy Pollack, Sexual Harassment: Women's Experience vs. Legal Definitions, 13 HARV. WOMEN's L.J. 35, 37-38 (1990).

${ }^{23}$ See Vicki Schultz, Sexual Harassment, INTERNATIONAL ENCYCLOPEDIA OF THE SOCIAL SCIENCES 7-8 (forthcoming 2001).

${ }^{24}$ See Mia Cahill, The Legal Problem of Sexual Harassment and Its International Diffusion: A Case of Austrian Sexual Harassment Law, 10-11 
substantive definition and the privatized enforcement mechanisms of the American approach; ${ }^{25}$ France criminalized what we would think of as quid pro quo harassment. ${ }^{26}$ These legal approaches failed to connect harassment to a larger system of workplace gender inequality that relegates women to inferior jobs; they simply accept the gender segregation of work as a "neutral" background condition rather than defining it as the structural context in which harassment flourishes (and which it fosters).

I encountered this same lack of understanding when I taught a session on sexual harassment at a conference on global constitutionalism a few years ago at Yale. ${ }^{27}$ Apart from the one U. S. Supreme Court Justice who was present, ${ }^{28}$ many high-level jurists from around the world simply did not appear to comprehend what I was saying about the link between sex segregation of employment and hostile work environment harassment. They viewed sex harassment exclusively as a form of sexual imposition (akin to rape), and many of them used legal discourses that defined sexual advances against a woman as a violation of her basic human dignity. Now, it's not that I don't believe sexual advances can ever infringe on interests we might think of as dignitarian in nature; of course they can. ${ }^{29}$ But to legally equate sexual advances toward women with inherent violations of women's dignity strikes me as

(2000) (unpublished manuscript, on file with the Journal of Law and Policy) (showing that the European Union definition of sexual harassment relied greatly on the definition from the EEOC guidelines, especially the emphasis on conduct of a sexual nature).

${ }^{25}$ Id. at 14-15, 22-23.

${ }^{26}$ See Abigail C. Saguy, Sexual Harassment in France and the United States: Activists and Public Figures Defend Their Definitions, in COMPARING POLITIES AND REPERTOIRES OF EVALUATION IN FRANCE AND THE UNITED STATES 19 and n.34 (Michele Lamont \& Laurent Thevenot, eds., 2000) (manuscript forthcoming, on file with the Journal of Law and Policy) [hereinafter Saguy, Sexual Harassment in France].

${ }^{27}$ Conference on Global Constitutionalism, Equality: International Norms, Session on Sexual Harassment, Yale Law School, New Haven, Connecticut, 1998.

${ }^{28}$ Justice Stephen Breyer attended the conference, and he clearly understood my point.

${ }_{29}^{29}$ See, e.g., Anita Bernstein, Treating Sexual Harassment with Respect, 111 HARV. L. REV. 445 (1997). 
a reductionist, potentially dangerous move that feminists should evaluate very carefully.

A related problem with harassment law's focus on sexual misconduct is that it invites inquiry into the sexual history and sexual self-presentation of the person who was harassed. In current harassment doctrine, for example, the law asks whether the sexual advances or conduct were "unwelcome." Now, under a work-based model of the type that I am advocating, we would not need such an unwelcomeness standard, because it would make no sense to ask whether someone had welcomed being subjected to an environment that interfered with their ability to pursue their work. "Did the harassee welcome being driven out of her job?" "Did she welcome being made to look incompetent?" These are not questions that would be on our radar screen. But once we have a model that focuses on sexual advances and other sexual activity, we do have to have something like an unwelcomeness standard because we don't want to prohibit all sexual activity.

Some sexual advances and other forms of sexual activity are desired and invited, even in the workplace. Yet, once we have an unwelcomeness standard, we know from past experience that courts will abuse it and allow inquiry into whether the victim behaved in such a way as to welcome her own harassment. ${ }^{30}$ In the hostile work environment context, there are shocking cases, such as one case in which the court deemed a woman to have "welcomed" such actions as having her head pushed in the toilet, being shocked with a cattle prod, being maced, and being hit and punched in the kidneys - simply because she had had the temerity to use profanity, tell off-color jokes, flirt, and go without a bra. ${ }^{31}$ There is a

${ }^{30}$ See Susan Estrich, Sex at Work, 43 STAN. L. REV. 813, 826-35 (1991).

${ }^{31}$ See, e.g., Reed v. Shepard, 939 F.2d 484, 486-87 (7th Cir. 1991) (holding that the "unwelcomeness" requirement was not met where a female jailer claimed that she was "handcuffed to the drunk tank and sally port doors, ... that she had chairs pulled out from under her, a cattle prod with an electrical shock was placed between her legs, and that ... [she was] handcuffed to the toilet and her face pushed into the water, and maced," all on the ground that she had used profanity, told off-color jokes, engaged in sexual horseplay and flirting, and failed to wear a bra underneath her T-shirt); see also Weinsheimer v. Rockwell, 754 F. Supp. 1559, 1565 (M.D. Fla. 1990), aff'd, 949 F.2d 1162 (11th Cir. 1991) (rejecting sexual harassment claim on the ground that the unwelcomeness 
problem when the victim has to meet an image of a Sunday school teacher in order to win a harassment case. ${ }^{32}$ The law separates the good girls from the bad girls, and punishes the latter. ${ }^{33}$

When the law has this sexual focus, it is not only women who are harmed. The focus on rooting out unwelcome sexual advances permits those who enforce the law to condemn not just bad girls, but also other people whom our culture views as the walking embodiments of dangerous or offensive sexuality. We can predict who such people will be: women and men of color, working class men and women, gay men and lesbians, bisexuals and transgendered people, and other sexual minorities. ${ }^{34}$ The courts can deem

requirement was not met where plaintiff had engaged in sexual banter and joking and had used "abusive and vulgar language" in speaking to her boyfriend on the telephone at work).

${ }^{32}$ I believe Anita Hill fell victim to this phenomenon. At first, her credibility was high because she came across as a prim, school teacher type. Eventually, however, "[h]er veracity, her motives, her private life, and even her sanity would come under assault. It would require an intense effort, but Hill's apparently pristine character would . . be completely transformed." JANE MAYER \& JILL ABRAMSON, STRANGE JUSTICE: THE SELliNG OF CLARENCE THOMAS 280 (1994). By the time the Senate hearings were over, "[s]he had been portrayed as, among other things, a political zealot, a sexual fantasist, a scorned woman, possibly a closet lesbian, and a pathological liar who had lifted bizarre details from The Exorcist in a desperate effort to destroy Thomas." Id. at 305.

${ }^{33}$ I have analyzed this problem in greater depth elsewhere. See Schultz, Reconceptualizing Sexual Harassment, supra note 3, at 1744-45.

${ }^{34}$ See, e.g., Nan D. Hunter, Identity, Speech, and Equality, 79 VA. L. REV. 1695 (1993) (documenting the role of homosexual identity in the state's regulation of sexuality); Nan D. Hunter, Life After Hardwick, 27 HARV. C.R.C.L. L. REV. 531 (1992) (arguing that the regulation of sexuality threatens reinforcing or increasing the social penalty accruing to disfavored sexualities). Cf. Carlin Meyer, Sex, Sin and Women's Liberation: Against Porn-Supression, 72 TEX. L. REV. 1097, 1119-20 (1994) (noting that, in the context of pornography regulation, "judges, jurors, and most members of the public are likely to find most explicit or 'deviant' sexual depictions repellant and view as degrading not only sexual portrayals that descriptively, humorously, playfully, or ironically depict subordinated women, but also those that are explicitly intended to challenge that subordination"); Nadine Strossen, A Feminist Critique of "The" Feminist Critique of Pornography, 79 VA. L. REV. 1099, 1145-47 (1993) (stressing that censorship of pornography would likely be used against homosexuals, feminists, and those perceived to have deviant sexuality, and 
such people outside the bounds of legal protection extended to harassees - or, worse yet, stigmatize them as harassers.

A good example of this kind of targeting of a sexual minority is the double standard courts have adopted with respect to gay men (or those presumed to be gay) in sex harassment cases. ${ }^{35}$ The courts have characterized male bosses who make sexual advances toward men as harassers, on the ground that the boss would not have been attracted to and therefore would not have made a similar advance toward a woman. This reasoning, of course, presumes that the bosses are homosexuals who have desire only for men, and uses that presumption as the basis for finding them guilty of sex harassment. ${ }^{36}$ By contrast, however, the courts have almost never

reporting allegations that Canadian customs censors have singled out gay and lesbian, as well as radical, bookstores).

${ }^{35}$ See Schultz, Reconceptualizing Sexual Harassment, supra note 3, at 17771785 (analyzing in detail this double standard); see also Kenji Yoshino, The Epistemic Contract of Bisexual Erasure, 52 STAN. L. REV. 353 (2000) [hereinafter Yoshino, The Epistemic Contract] (arguing that courts have set up a two-tiered system of justice for homosexual and heterosexual harassers).

${ }^{36}$ See, e.g., Yeary v. Goodwill Indus.-Knoxville, Inc., 107 F.3d 443, 448 (6th Cir. 1997) ("When a male sexually propositions another male because of sexual attraction, there can be little question that the behavior is a form of harassment that occurs because the propositioned male is a male - that is, "because of . . sex."'); Wrightson v. Pizza Hut of Am., Inc., 99 F.3d 138, 143 (4th Cir. 1996) ("We hold that a same-sex 'hostile work environment' sexual harassment claim may lie under Title VII where a homosexual male (or female) employer discriminates against an employee of the same sex or permits such discrimination against an employee by homosexual employees of the same sex."); McWilliams v. Fairfax County Bd. of Supervisors, 72 F.3d 1191 (4th Cir. 1996) (holding that same-sex sexual harassment claims could be actionable if and only if the defendant is shown to be homosexual).

There is a more theoretical objection to this line of reasoning - indeed, to the entire edifice of "but-for" reasoning that undergirds the cause of action for quid pro quo harassment perpetrated by those presumed to be exclusively heterosexual or homosexual. This "but-for" reasoning first emerged in early cases involving heterosexual male supervisors who fired women who refused their sexual advances. In these cases, the courts faced a dilemma: just what was it about this situation that constituted discrimination "because of sex" within the meaning of Title VII? Early courts held that the male supervisor's sexual advance amounted to discrimination because of sex because the supervisor had made an advance toward a woman that he would not have made toward a man. 
extended protection from sex harassment to gay men (or men who are presumed gay), even when they are subjected to overt, genderbased harassment at the hands of straight (or presumably straight) men. ${ }^{37}$ (I am talking about men here because most of the cases with which I am familiar involve men. But I suspect that this pattern would hold in cases involving women as well. $)^{38}$

This problem of the normalization of some kinds of sexuality at the expense of others ${ }^{39}$ raises the prospect that the conventional sexual model of harassment law may tread too heavily on free expression - especially the sexual expression of unpopular groups. Of course, this is a complex subject about which people of good

See, e.g., Barnes v. Costle, 561 F.2d 983 (D.C. Cir. 1977). Although it may not be obvious at first blush, this reasoning actually identifies as the source of sex discrimination the sexual attraction or desire presumed to underlay the supervisor's sexual advance. For, according to the courts' logic, the only reason the heterosexual supervisor made an advance toward the woman that he would not have made toward a man is that the supervisor felt an attraction or desire for her that he would not have felt for a man. The courts applied the same logic to male supervisors who made advances toward men who worked for them, reasoning that the supervisors (who they presumed were homosexual) would not have felt desire for and therefore would not have made advances toward women - only for men. This reasoning is objectionable on many levels. As my colleague Kenji Yoshino has pointed out, it negates the possibility of bisexual desire. See Yoshino, The Epistemic Contract, supra note 35. Even more fundamentally, one might object, as I do, to the fact that it singles out sexual desire as the source of legal prohibition - or, put colloquially, it outlaws desire.

${ }^{37}$ See, e.g., Spearman v. Ford Motor Co., 231 F.3d 1080 (7th Cir. 2000) (holding that harassment of a gay male employee by male co-workers and male supervisor was not harassment "because of sex"); Dillon v. Frank, No. 90-2290, 1992 U.S. App. LEXIS 766, *15 (6th Cir. Jan. 15, 1992) (male worker harassed by male co-workers who thought he wasn't "macho" enough); see also Doe by Doe v. City of Belleville, 119 F.3d 563 (7th Cir. 1997) (man accused of being gay harassed by straight male co-workers); Goluszek v. Smith, 697 F. Supp. 1452 (N.D. Ill. 1988) (same). For analyses that question and complicate the courts' presumptions about the sexual orientations/desires of harassers and even the harassees, see Yoshino, The Epistemic Contract, supra note 35.

${ }^{38}$ See, e.g., Johnson v. Cmty. Nursing Services, 985 F. Supp. 1321 (D. Utah 1997) (female supervisor made sexual advance toward female employee); Myers v. City of El Paso, 874 F. Supp. 1546 (W.D. Tex. 1995) (same).

${ }^{39}$ See Michael Warner, The Trouble with Normal: SeX, Politics, AND THE ETHICS OF QUEER LIFE (1999). 
will can disagree. But it is not only conservatives who should be worrying about this issue $;^{40} \mathrm{I}$ believe feminists and liberals should also be doing so. ${ }^{41}$ We should make sure that harassment law does not give employers an incentive - or excuse - to fire ordinary workers for engaging in benign sexual expression in the name of protecting women.

Corporations have long had an incentive to suppress and control sexuality in the workplace. With the emergence of Taylorism in the early twentieth century, managers sought to sanitize their companies of emotionality and the other messy stuff of human life they saw as interfering with the rational functioning of the firm: ${ }^{42}$ reproduction, birth, death, sickness, disease, love, and sexuality. ${ }^{43}$

${ }^{40}$ For some insightful analyses of this problem by conservative commentators, see Kingsley Browne, Title VII as Censorship: Hostile-Environment Harassment and the First Amendment, 52 OHIO ST. L.J. 481 (1991); Eugene Volokh, Comment, Freedom of Speech and Workplace Harassment, 39 UCLA L. REV. 1791 (1992); Eugene Volokh, What Speech Does "Hostile Work Environment" Harassment Law Restrict? 85 GEO. L.J. 627 (1997).

${ }^{41}$ For some good analyses by scholars with a feminist perspective, see J. M. Balkin, Free Speech and Hostile Environments, 99 ColuM. L. REV. 2295 (1999); Cynthia L. Estlund, Freedom of Expression in the Workplace and the Problem of Discriminatory Harassment, 75 TEX. L. REV. 687 (1997).

${ }^{42}$ Taylorism is a theory of management introduced by Frederick Winslow Taylor, who introduced ideas of scientific precision into the world of worker management. See John Fabian Witt, Note, The Transformation of Work and the Law of Workplace Accidents, 107 YALE. L.J. 1467, 1488 (1998) ("Taylor developed a series of new managerial techniques, including standardized and minutely controlled processes of production and maintenance, and stopwatch time-study to replace workers' informal know how with ostensibly scientific rationality."); see also ROBERT KANIGEL, THE ONE BEST WAY: FREDERICK WINSLOW TAYLOR AND THE ENIGMA OF EFFICIENCY (1997); ROSABETH MOSS KANTER, MEN AND WOMEN OF THE CORPORATION 20-22 (1977).

${ }^{43}$ There is evidence that the old bureaucratic paradigm is in the process of being replaced. See Vicki Schultz, Life's Work, supra note 7, at 1919-28 (documenting the shift from the old bureaucratic workplace to newer, more fluid forms of work organization); Katherine V.W. Stone, The New Psychological Contract at 3 (Jan. 31, 2000) (unpublished manuscript, on file with the Journal of Law and Policy) (discussing the shift to a new employment regime characterized by less employment security and more emphasis on "general skills training, upskilling of jobs, networking opportunities and contact with firm constituents for employees at all levels of the firm, micro-level job control, market-based pay, 
This same reasoning persists today. As I have heard many people put it, "Well, of course we should eliminate sexual harassment, because when people are at work, they have no business fooling around; they should be working." 44 Sex harassment law may provide an extra push for management to ban sexual interaction across-the-board, without worrying about whether it is welcome or unwelcome (even though the company would not be held liable for conduct that was not unwelcome). This incentive may explain why we are beginning to see policies that are disturbing from a genderequality perspective: policies prohibiting men and women from traveling together on business, policies preventing male supervisors from meeting with their female staff behind closed doors, and even policies prohibiting dating or sexual joking among employees. ${ }^{45}$

We need a feminist approach to sex harassment that avoids these pernicious effects and articulates an alternative normative vision. Even if we could banish all hints of sexuality from the workplace - the place where we spend most of our waking hours - this would not represent progress. On the contrary, I think it is part of a feminist vision of progress to be able to express ourselves freely and to be more fully human while we are at work. Now, of course, we all have to respect other people, and we need to get along well enough to work together to achieve common goals. But we should not allow some people to censor what their co-workers say simply because they are offended. When people are being fired for sexual harassment simply because they show a dictionary

and firm-specific dispute resolution institutions for ensuring fairness"). It remains to be seen whether the new, more fluid forms of work organization will take a different approach to matters of emotionality, sexuality, and the like.

${ }^{44}$ Sociologist Abigail Saguy has documented a strand of American feminist thought that also emphasizes this same productivity-oriented rationale for regulating sexual harassment. See Saguy, Sexual Harassment in France, supra note 26 at $15-16$.

${ }^{45}$ Tamar Lewin, Debate Centers on Definition of Harassment, N.Y. TIMES, Mar. 22, 1998, at Al (noting that some employers "have tried to de-sexualize the workplace, adopting codes forbidding intra-office dating, touching or staring"); Kate Zernike, A New Sexual Harassment Dynamic, Boston GlOBE, May 18, 1998 , at A1 (noting that "companies have ruled out travel involving two colleagues of the opposite sex" and many "have banned romantic relationships"). 
definition of the word "clitoris" to a female co-worker, ${ }^{46}$ we should be concerned that feminism is being used in the service of Fordism. ${ }^{47}$

Feminists should aspire to do much more. We should aspire to create a world in which people do not have to suspend our basic humanity while we are at work. We should aspire to create a world in which women as well as men, sexual minorities as well as those in the sexual mainstream, can be perceived as sexual beings and competent workers at the same time - a world where sexuality, humanity, and authority coexist for all. To do this, we must create workplaces in which women as well as men, people from all walks of life, occupy the structural positions of equality and authority that are necessary to endow us with us with the capacity to engage in free and equal expression - including sexual expression.

I could say more about how my approach to harassment gets us closer to these goals. The basic idea is to create a body of law that gives companies the incentive to fully integrate their workplaces along sex/gender lines, but does not spur them to censor benign sexual expression in the name of protecting women from sexual harassment. But I'm out of time.

${ }^{46}$ Miller Brewing Company was assessed $\$ 26.6$ million in damages after the company fired a male executive whom a female employee had accused of sexual harassment. See James L. Graff, It Was a Joke! An Alleged Sexual Harasser Is Deemed the Real Victim, TIME, July 28, 1997, at 62. The executive had related to the employee an episode of Seinfeld in which Seinfeld cannot remember the name of the woman he is dating, but he knows it rhymes with a part of the female anatomy. Id. When the employee did not get the joke, the executive photocopied a dictionary page defining "clitoris" and handed it to her. Id.

${ }^{47}$ Stone, The New Psychological Contract, supra note 43, at 9-11 (describing Fordism's impulse to rationalize and standardize the organization of work). 
